\title{
25 Research Soure \\ Characteristics of undergraduate, second speciality and sub-speciality mental health programmes in Peru: a scoping review
}

\author{
Jackeline García-Serna \\ Instituto Peruano de Orientación Psicológica \\ Jessica Hanae Zafra-Tanaka \\ Universidad Científica del Sur \\ Jeff Huarcaya \\ Universidad San Ignacio de Loyola. Lima \\ Ana Lucia Vilela-Estrada \\ Instituto Peruano de Orientación Psicológica \\ Guillermo Almeida-Huanca \\ Instituto Peruano de Orientación Psicológica \\ David Villarreal-Zegarra ( $\nabla$ davidvillarreal@ipops.pe ) \\ Instituto Peruano de Orientación Psicológica
}

\section{Research Article}

Keywords: Education Medical, Education Nursing, Health Personnel, Community Mental Health Centers.

Posted Date: February 15th, 2022

DOI: https://doi.org/10.21203/rs.3.rs-1303396/v1

License: (c) (i) This work is licensed under a Creative Commons Attribution 4.0 International License. Read Full License 


\section{Abstract}

Background: Peru has a deficit in mental health care with 10,051 mental health workers per 100,000 inhabitants. The aim of this study was to characterise the offer of undergraduate and second speciality mental health programmes in Peru.

Method: We conducted a scoping review of mental health training offered by Peruvian universities. We searched for programmes in the University Information System database and on the universities' websites. We extracted the name of the university, the name of the programme, the target population, the duration, the cost, the learning environment, the region, and the type of institution where they are offered. We collated the information and used descriptive statistics to analyze the data.

Results: We found a total of 252 undergraduate and 63 second speciality programmes, with $43 \%$ and $54 \%$ of the programmes respectively offered in the capital city. Undergraduate mental health programmes last between 3 and 7 years and cost between US\$ 55.71 and US\$ 6,952.03 in private universities for the first semester. As for second speciality programmes, the total cost of the programme varies from US\$ 729.26 to US\$12,140.17, where the latter offers more practical training for physicians and nurses.

Conclusions: In Peru, there are few undergraduate programmes oriented towards social work and medical technology (focused on occupational therapy and speech therapy), as well as a few second speciality programmes for psychologists. This affects the possibility of having multidisciplinary teams trained in mental health. We believe that to improve the competencies of professionals to manage mental health problems, institutions involved in health and education should develop policies to decentralise programmes, make them more accessible to lowincome people, respond to mental health issues, and ensure the quality of all programmes.

\section{Background}

By 2030, it is estimated that there will be a deficit of 15 million health professionals globally, and the estimated deficit in Latin America and the Caribbean will be 2.6 million professionals [1]. Globally, there are 9 mental health professionals (psychiatrists, nurses, psychologists, social workers, occupational therapists or speech therapists) per 100,000 inhabitants [2]. In particular, South America has less than the world average, with 8.8 mental health professionals per 100,000 inhabitants, the majority of which are psychologists $(8.6 / 100,000)$ and the minority are psychiatrists $(2.4$ / 100,000) [3]. Estimated that 59\% of low- and middle-income countries lack sufficient mental health professionals to adequately cover health care [4].

In 2016, mental and behavioural disorders were the leading cause of years of life lost in Peru [5]. Peru already had a deficit in access to health services, with larger gaps in rural areas (69 and 93.2\% gap in urban and rural capital city, respectively) [6]. Faced with this, a year earlier, in 2015, the regulation of the Law modifying article 11 of the "General Health Law, which guarantees the rights of people with mental health problems" through access to intervention, prevention, treatment, recovery and psychosocial rehabilitation, with a community approach, was approved [7]. However, to achieve health goals and universal health coverage, shortages, uneven distribution and performance-related problems of the health workforce need to be addressed [8].

In Peru, for a population of more than 31 million in 2017 [9], there were 2.95 psychiatrists, 0.21 child psychiatrists, 1.02 mental health nurses, 9.51 psychologists, 0.36 social workers, 0.09 occupational therapists and 0.12 speech therapists per 100,000 inhabitants [10]. Although the World Health Organization considered one psychiatrist per 
10,000 population to be adequate [11]. The shortage and inequity in the distribution of health personnel are present throughout the health system, so the Peruvian Ministry of Health established five objectives 1) Strengthen the stewardship of Human Resources in Health (HRH), 2) Provide sufficient HRH to reduce inequity, 3) Strengthen professional competencies to respond to the demands of the population, 4) Increase working conditions according to the aspects of decent work for health personnel and 5) Achieve efficient job performance of $\mathrm{HRH}$ [12].

Given the mental health burden in Peru and the shortage of specialised professionals, there is a need to improve mental health care focusing on the training of the health workforce [13]. This leads to the need for high-quality training programmes, with sufficient numbers of professionals to address mental health problems and close the care gap. The need for more mental health professionals implies the expansion of the number of educational programmes [14].

\section{Method}

\section{Aim}

The present study aims to characterise the offer of undergraduate and second speciality mental health programmes, taking as a reference the personnel requirements published by the Ministry of Health for the management of mental health problems in the community [15].

\section{Design}

We conducted a scoping review of undergraduate and second professional speciality programmes (equivalent to speciality training in the medical career or postgraduate programmes for other health professionals) on mental health offered in Peruvian universities. In Peru, the National Superintendence of Higher Education licenses universities to operate, based on quality standards [16]. Therefore, we included in our scoping review the universities licensed by this institution. We opted for a scoping review, as it allows us to assess the nature and scope in areas of study with little material available [17]. We followed the PRISMA-ScR guidelines.

\section{Context}

In Peru, there are currently 203 Community Mental Health Centres [18], providing specialised mental health services in all regions of the country [7]. They need specialised staff like a psychiatrist (specialised in child and adolescent or addictions), community family medicine professionals, psychologists (trained in child, adolescent or family therapy, cognitive behavioural therapy or psychoanalysis), nurses (specialised in mental health and psychiatry or public health), medical technologists (specialised in speech therapy or occupational therapy) and social workers [15].

However, the Ombudsman's Office reported that the Community Mental Health Centres do not have enough trained staff (see Supplement 1) [19]. In this context, in Peru, the duration of undergraduate training for health personnel lasts from 3 to 7 years and specialised training lasts from 1 to 3 years, for which physicians and nurses must take an exam and enter a health centre for training, where learning is focused on clinical tools [20].

\section{Registration Protocol and ethical aspects}


This study did not require ethics committee approval as no human subjects were involved. The initial protocol can be found in the supplementary material section (see Supplement 2).

\section{Eligibility Criteria}

We selected undergraduate, second speciality and sub-specialities programmes offered by Peruvian universities authorised by The National Superintendence of University Higher Education at the national level. The undergraduate programmes are taken at the university and lead to a university degree. Second speciality programmes are considered as postgraduate studies that are taken at the end of the undergraduate degree. Finally, sub-speciality is pursued after the second speciality and are common in medicine.

For this research, we selected programs based on the staffing requirements of Community Mental Health Centres [15]. Therefore, we chose to assess programs on medicine, nursing, nursing technician, psychology, social work and medical technology (focus on occupational therapy and speech therapy). As for the second specialisations, we chose psychiatry, addiction psychiatry, child and adolescent psychiatry and community family medicine (aimed at physicians); second specialisation in mental health and public health (aimed at nurses); second specialisation in cognitive behavioural therapy and family therapy (aimed at psychologists) and speech therapy (aimed at health personnel in general).

\section{Sources of information}

We searched for programmes through two sources, the University Information System database and the websites of each university. The University Information System is a virtual platform created by the National Superintendence of University Higher Education (SUNEDU, by its acronym in Spanish), which provides information about the programmes offered by licensed universities [21]. On the platform, we review the profiles of the licensed universities and the undergraduate and second speciality programmes and we identify mental health focused programmes. Then, we contrasted and complemented this search with the search on the websites of each university.

\section{Selected data}

We used a data extraction form, which was tested and improved by the team according to the research objective. We extracted the 1) name of the university, 2) name of the programme, 3) region where the programme was offered, 4) type of institution (university or institute); 5) target population, 6) duration in years, 7) university management (public or private), 8) cost per study (monthly fees and tuition), 9) total cost of the programme (tuition, monthly fees and enrolment), and 10) Form of learning (this refers to mainly theoretical, or mainly practical learning). Elements 9 and 10 were only applied to second speciality programmes. Likewise, second speciality programmes for physicians also include payment to the National Council of Medical Residencies (CONAREME, by its acronym in Spanish), which directs the National Competition for Entry to Medical Residency for access to second speciality programmes in medicine [22]. All data extracted during the review process can be found in Supplement 3.

\section{Procedure}


We used the University Information System platform and found 94 universities and 21 institutes, with authorization from the National Superintendence of University Higher Education. That number did not change until the final data collection date (October 5,2021 ). We then reviewed each profile to identify whether they offered the programs defined in the eligibility criteria section and corroborated the currency of the programs by searching for them in parallel on the universities' websites. Subsequently, two people performed the data extraction specified in the Data Selection section. Finally, when we found inconsistencies in the extracted data, we performed a third search of the program to corroborate it.

\section{Synthesis of the results}

Data were extracted using a Microsoft ExcelTM spreadsheet (Microsoft Corp., Redmond, Washington, USA). The unit of analysis was undergraduate and second speciality programmes. Descriptive analysis was performed using Excel software and $\mathrm{R}$ [23]. On the undergraduate programmes, information was provided on their geographical distribution, duration, type of management of the universities offering them and cost. Regarding the cost, private universities had two payment modalities, a general cost for the public or a scale of costs, with minimum and maximum prices designated based on the management of the applicant's school (pay scale). The cost of private universities was reported as a minimum and maximum overall cost and the mean of the lowest and highest scale of the pay scale. For specialised training programmes we report the number of programmes by target audience, their geographical distribution, duration, management type, total cost and mode of instruction. Each price will also have an equivalent in Peruvian minimum living wage (MLW), which is 238.68 dollars (exchange rate on 12 January 2022) [24]. We also present the results in tables and graphs.

\section{Results}

\section{Undergraduate mental health training programmes}

At the national level, we found 252 programmes offered by 64 universities and 21 institutes of higher education distributed in the 25 regions of Peru (see Figure 1). Of the total of programmes, $28 \%(n=70)$ were in nursing, $32 \%$ $(n=81)$ in psychology, $19 \%(n=48)$ in medicine, $4 \%(n=11)$ in social work, $1 \%(n=2)$ in medical technology with speech therapy orientation, $1 \%(n=2)$ in medical technology with occupational therapy orientation, and $15 \%(n=$ 38) in nursing technicians.

\section{Undergraduate Medicine programmes}

Of the total, $35 \%$ of programmes are located in the capital city. The duration is seven years and $58 \%$ of programmes are private. The cost of the first semester at a public university can be free or cost US\$ $25.32(0.1$ MLW). In private universities the cost varies from US\$ 763.45 (3.2 MLW) to US\$ 6,952.03 (29.5 MLW). In terms of pay scale, the average of the lowest rating was US\$2,707.19 (11.5 MLW) and the average for the highest ranking was US\$ 3,816.05 (16.2 MLW).

\section{Undergraduate Psychology programmes}

Of the total, $46 \%$ of the programmes are located in the capital city. The duration oscillates between five and six years and $73 \%$ of programmes are private. The cost of the first semester at a public university can be free or cost 
US\$ 25.32 (0.1 MLW). In private universities, the cost varies from US\$ 456.29 (1.9 MLW) to US\$ 5,902.46 (25.1 MLW). In terms of the pay scale, the average of the lowest rating was US\$1,072.00 (4.6 MLW) and the average for the highest rankings was US\$1,829.50 (7.8 MLW).

\section{Undergraduate Nursing programmes}

Of the total, $31 \%$ of the programmes are located in the capital city. The duration is five years and $38 \%$ of programmes are private. The cost of the first semester at a public university can be free or cost US\$25.32 (0.1 MLW). In private universities, the cost varies from US\$ 414.77 (1.8 MLW) to US\$1,745.92 (7.4 MLW). In terms of the pay scale, the average of the lowest rating was US\$ 807.36 (3.4 MLW) and the average for the highest ranking was US\$ 1,093.63 (4.6 MLW).

\section{Undergraduate Nursing technician programmes}

These types of programmes are offered in institutes; of the 38 programmes we did not find information on five programmes. In addition, the institutes do not use the pay scale system. Of the total, $66 \%$ of the programmes are located in the capital city. The duration is three years and $97 \%$ of programmes are private. The cost of the first semester at a public institute can be free or cost US\$50.64 (0.2 MLW). In private institutes the cost varies from US\$ $55.71(0.2 \mathrm{MLW})$ to US\$532.01 (2.3 MLW). No pay scale was identified in this training program.

\section{Undergraduate Social work programmes}

Of the total, $27 \%$ of the programmes are located in the capital city. The duration is five years and $82 \%$ of programmes are public. In the case of these programmes, the cost is the same for all and no sliding scale is used. The cost of the first semester at a public university can be free or cost US\$ $12.66(0.1 \mathrm{MLW})$ and in private universities the cost varies from US\$ 505.42 (2.1 MLW) to US\$ 671.02 (2.8 MLW).

\section{Undergraduate Medical Technology programmes focus on speech and occupational therapy}

All programmes are located in the capital city. The duration is five years and $50 \%$ of programmes are private. The cost of the first semester at a public university can be free. In private universities the cost varies from US\$ 1,343.31 (5.7 MLW) to US\$1,700.34 (7.2 MLW). As for the pay scale, this was not done, as only one private university offers both programmes.

\section{Second speciality and sub-speciality training programmes in mental health.}

We found 65 second speciality programmes in the University Information System database but eliminated two (Second Speciality in Community and Social Psychiatry; Therapeutic Psychology), the first because it was no longer open and the second because it was being restructured. At the national level, we found 252 programmes offered by 64 universities and 21 institutes of higher education distributed in the 25 regions of Peru with $43 \%$ of them offered in the capital city (see Figure 1). Physicians were the main target of the programmes $(60 \%, n=38)$, 
followed by nurses $(25 \%, n=16)$, psychologists $(6 \%, n=4)$ and the general health public $(8 \%, n=5)$. Of the 63 programmes, 10 were missing some elements, such as the cost per study, the total cost or the duration of the programme. Cases with missing data were therefore excluded from the analysis.

\section{Second speciality and sub-speciality programmes for Physicians}

It is made up of the second speciality Psychiatry, Community Family Medicine and the sub-specialities Addiction Psychiatry and Child and Adolescent Psychiatry (see table 1). We found that $55 \%$ of the total was offered in the capital city, the duration is three years for specialities and two years for sub-specialities; and $58 \%$ of the programmes were offered in private universities. The total cost of second speciality programmes ranges from US\$ 3,274.58 (13.9 MLW) to US\$ 12,140.17 (51.6 MLW), while sub-specialities range from US\$2,297.17 (9.8 MLW) to US\$ 9,255.54 (39.3 MLW). Their learning environment is mainly hospital-based.

\section{Second speciality programmes for Nurses}

It is composed of the second specialisations of mental health nursing, mental health and psychiatric nursing, and public and community health nursing (see Table 2). We found that $63 \%$ of the programmes are offered in the capital city, the last one to two years and $25 \%$ of them are offered in private universities. The total cost of the second specialities ranges from US\$ 729.26 (3.1 MLW) to US\$3,532.36 (15 MLW) and their learning environment is mainly hospital-based.

\section{Second speciality programmes for psychologists}

It consists of the second specialisations in Systemic Family Psychotherapy and Cognitive Behavioural Therapy (see Table 3). We found that $50 \%$ of the programmes are located in the capital city, the duration is one to two years and $50 \%$ are offered in private universities. The cost of the second speciality ranges between US\$ 835.61 (3.5 MLW) and US\$2,671.42 (11.3 MLW) and its learning environment is mainly theoretical.

\section{Second speciality programmes of mental health multidisciplinary}

It is composed of second speciality programmes in Speech and Language Therapy aimed at health care personnel (see Table 4). We found that $60 \%$ of the programmes are offered in the capital city, the duration of the programmes varies from one to two years and $80 \%$ are offered in private universities. The cost ranges from US\$ 835.61 (3.5 MLW) to US\$2,476.45 (10.5 MLW) and the learning environment varies from theoretical to hospital-based.

\section{Discussion}

\section{Estimation and distribution of undergraduate and postgraduate programmes}

One of the consequences of the unequal distribution of programmes is the migration of students. Since many young people from disadvantaged communities see education as a way out of poverty, the search for better education is one of the reasons they migrate [25]. However, it is not certain that these professionals will return to 
their place of origin, as cities where there is more opportunity for education tend to offer better and more employment opportunities [26]. Thus, the unequal distribution and concentration of mental health programs in the capital city reinforce migration in those who want to pursue such programs and demotivates those who want to stay in their regions of origin.

In addition, we found few undergraduate medical technology programmes in the area of speech and occupational therapy as well as social work. The shortage of the first two programmes is reflected in the Ombudsman's report in Peru [19]. This implies a danger for services dedicated to children and the elderly. This situation is associated with the fact that the demand for certain areas of medical technology is not visualised by the $\mathrm{MOH}$, replacing the functions of medical technologists with other professionals and resulting in few universities offering the programmes [27].

\section{Characteristics of undergraduate and postgraduate programmes}

At the undergraduate level, public universities offer free tuition, but they are very selective and require a high level of preparation [28] making it difficult for many students to enter. Although private universities are less selective, their average monthly cost is more than US\$111.95, which varies according to the programme and the university chosen [29]. In this context, the economic factor stands out as a trigger for the interruption of studies, as in 2018, $47.7 \%$ of Peruvian students who interrupted their studies were from the lowest economic level [28].

In terms of the quality of universities, rankings are currently used. Among them, the international higher education consultancy Quacquarelli Symonds (QS) based on 6 indicators (e.g. academic reputation and employer reputation) presented the QS World University Rankings 2022 [29]. This ranking included 8 Peruvian universities, of which five (PUCP, UPCH, UNMSM, UPC, USIL) have health careers. Of these, only UNMSM is public, but it has a very high selectivity, in 2018 it had 60,070 applicants and offered only 7,017 vacancies [30]. This makes access to quality education difficult, with few universities in the ranking, all located in the capital and mostly private.

As far as second speciality programmes are concerned, we found similarities and differences with programmes in other countries in terms of the duration, place of training, the form of teaching, supervision and distribution.

In Asia, the training of psychiatrists lasts one year longer than in Peru [31], and the place of training is similar, such as university facilities, psychiatric units of general or mental health hospitals [31],[32]. Also, one approach to training in psychiatry in Japan is to offer more active, clinical, social and behavioural science-based learning [33], while in Peru the biological paradigm predominates [34]. For whom, normal is the standard for a given situation, becoming a statistical health pattern, adopting an excluding and differentiating character, generating limitations in health care and not adjusting to the biological-ecological and social reality [35],[36]. The biological paradigm is important, but it cannot encompass the complexity of the human disease process and treatment [37]. On the other hand, in Europe, the European Union of Medical Specialists governs the quality control mechanisms of training programmes [38], while in Latin America each country has its institutions and standards.

In Spain, there is a heterogeneous distribution of training programmes in nursing, with a duration of one year and no standard for the teaching of the speciality [39]. Similarly, in Peru, most speciality programmes are offered in the capital city of Peru, and there is no standard for teaching. In contrast, the UK has developed speciality programmes with criteria such as defining the target population, including evidence-based approaches, developing core competencies from the chosen approach and others [40]. It would therefore be more appropriate to establish 
standards that allow for better professional training through mechanisms that guarantee continuous supervision, quality assurance in training programmes, as well as validation that authorises the transfer of a mental health service provider from one country to another.

In terms of psychology training in Latin America, Argentina stands out for expanding the number of sites, with postgraduate programmes focused on clinical education to ensure coverage in the offer of professional training [41],[42] and the implementation of e-learning during the pandemic to reinforce clinical training through telehealth services [43]. Peru, on the other hand, has second speciality programmes centred in the capital city and largely theoretical, but having programmes in hospital settings or centres with guaranteed internships would consolidate the clinical competencies of health professionals [44],[45],[46]. In this regard, it is emphasised that training should be designed to prepare healthcare workers to perform their work in real-life conditions and thus prevent ineffective and inadequate outcomes during treatment by increasing the likelihood of recovery of users [47], [48].

Mental health reforms in Latin America seek a restructuring of hospital care services based on a community-based model [49]. In Peru, the shift from hospital care to community care to strengthen the role of the community in the treatment and rehabilitation of patients with mental disorders and increase access to care is highlighted [48],[49], [50]. This reform is generating progress with respect to the role of physicians and nurses. However, in the case of psychologists, there is no specific regulation that obliges hospitals or primary care centers to serve as a training environment based on professional quality standards, which could mean that they have fewer training opportunities compared to other health professionals.

On the other hand, as for the cost of second speciality programmes, these range from 3.1 to 51.6 times the minimum living wage, an expense that is borne by the professionals and which influences their decision on which programme to choose. Thus, for a group of medical students, the choice of a second speciality was mainly based on salary (23.6\%) and job opportunities (19.7\%), for a few of them on calling (8.9\%) [51].

Finally, it is worth mentioning that the programmes require teaching standards, but this was only found for second speciality medicine programmes and not for other health professionals. While the National Superintendence of Higher Education in Peru is evaluating the basic quality conditions of medical training programmes [52], this evaluation needs to be extended to programmes focusing on mental health. It is important to have an entity responsible for monitoring them to ensure that they maintain basic quality conditions.

\section{Public health and education implications}

In Peru, CMHCs as first-level centres, with an interdisciplinary team and a community approach [15], has generated significant levels of care at a lower cost than Specialised Psychiatric Hospitals. However, staff shortages hinder the expansion of health care, the implementation of policies and the structuring of health systems [53]. Measures need to be put in place to increase access to training programmes required by understaffed regions.

One proposal to increase access to training programmes is the decentralisation of supply and the evaluation of the relevance of selection and admission criteria [54]. A reference for increasing access to higher education was Brazil, which financed a network of public universities and tried to consolidate a network of public distance universities [55]. Another strategy to cope with the concentration of programmes in a few regions and geographical barriers is the e-learning model. However, this option requires access to the Internet, electronic devices such as 
computers [56], specialised staff to design the programmes, adapt e-learning to the reality of the participants [57] and train teachers [58]. Also, the model may limit learning to theoretical aspects or digital interventions, but one option is to combine online classes with rotations in hospitals, which would require contact with hospitals or first level centres for the development of classes and practices.

Another proposal, given the lack of programmes, is to prioritise entry vacancies for people from remote or lowincome regions [59]. Ensure the permanence of university students, as Chile has done by implementing scholarships to help cover certain expenses of university life [60] or expand education by having the central or regional health system establish agreements or support applicants with the payment of existing programmes in private universities.

\section{Strengths and Limitations}

The strengths of this study are the search for programs at the level of the campuses and branches of the universities, as well as the parallel search for programs on the University Information System platform and the universities' web pages. The former made it possible to estimate the number of programs more accurately and the latter made it possible to avoid overlooking recently created programs.

As for the weaknesses of the study, firstly, universities that were not licensed or were under evaluation by the National Superintendence of Higher Education were not considered. However, this should not affect research considerably, as unlicensed universities often cease their activities and their programmes cease to exist, while universities in the process of licensing have not yet demonstrated that they meet minimum quality criteria.

Secondly, some universities' websites do not provide complete information on the programmes, but we were able to find information on most of them. Thirdly, while our study allows us to have an overview of the educational offer, it does not allow us to have an overview of the current number of professionals available and to assess whether or not more supply is needed.

\section{Conclusions}

In Peru, there are few undergraduate programmes oriented towards social work and medical technology (focused on occupational therapy and speech therapy), as well as a few second speciality programmes for psychologists that respond to the needs of community mental health centres. The former affects the possibility of having more professionals in health centres, while the latter hinders the possibility of having professionals trained to work in specialised areas of mental health. Many programmes are centralised in the capital and offered in private universities whose programmes are equivalent to at least 1.8 minimum living wages per semester. While second speciality programmes are equivalent in total to at least 3.1 times the minimum living wage. We believe that to increase the number and quantity of competencies of mental health professionals, institutions involved in health and education should develop policies to decentralise existing undergraduate and second speciality programmes, make them more accessible to low-income people, make them responsive to the needs of the population, and guarantee the quality of all programmes involved in mental health.

\section{Abbreviations}

HRH: Human Resources in Health 
MLW: Minimum Living Wage

PUCP: Pontificia Universidad Católica del Perú

UPCH: Universidad Peruana Cayetano Heredia

UNMSM: Universidad Nacional Nacional de San Marcos

UPC: Universidad Peruana de Ciencias Aplicadas

USIL: Universidad San Ignacio de Loyola

\section{Declarations}

Ethics approval and consent to participate

Not applicable. This study does not collect primary data since it gathers public information from governmental sources or university web pages, which does not involve any ethical risk for the participants.

Consent for publication

Not applicable.

Availability of data and materials

All data generated or analyzed during this study are included in this article published in Supplement 3.

Competing interests

The authors have declared that no competing interests exist.

Funding

This study was funded by the Instituto Peruano de Orientación Psicológica. The funder had no role in the development of the protocol, data collection, data analysis, writing of the manuscript, or choice of journal.

Authors' contributions

JGS, JHZT, ALVE, and DVZ conceptualized the research idea. JGS, JH, and GAH performed data extraction. JGS, JHZT, and DVZ performed the development of the study methodology. JGS, JHZT, GAH, and DVZ performed the formal analysis. JGS, and DVZ performed the data visualizations. JGS wrote the Original Draft. ALVE and DVZ performed the study supervision. JHZT, JH, ALVE, and DVZ made comments, revisions, and edits to the manuscript. All authors reviewed and approved the final version.

Acknowledgments

The authors would like to thank Gianina Villegas-Flores and Darwin Castillo for their support in the initial stages of the project.

Authors' information

Page $11 / 21$ 


\section{References}

1. Liu JX, Goryakin Y, Maeda A, Bruckner T, Scheffler R: Global Health Workforce Labor Market Projections for 2030. Human Resources for Health 2017, 15(1):11.

2. World Health O: Mental health atlas 2017. Geneva: World Health Organization; 2018.

3. Organization PAH: Atlas of Mental Health of the Americas 2017. Washington, D.C.: PAHO; 2018.

4. Bruckner TA, Scheffler Rm Fau - Shen G, Shen G Fau - Yoon J, Yoon J Fau - Chisholm D, Chisholm D Fau Morris J, Morris J Fau - Fulton BD, Fulton Bd Fau - Dal Poz MR, Dal Poz Mr Fau - Saxena S, Saxena S: The mental health workforce gap in low- and middle-income countries: a needs-based approach. Bull World Health Organ 2011, 89(3):184-194.

5. MINSA: Carga de enfermedad en el Perú: Estimación de los años de vida saludables perdidos 2016: Ministerio de Salud; 2018.

6. MINSA: Plan nacional de fortalecimiento de servicios de salud mental comunitaria 2018 - 2021. Documento técnico. Perú: MINSA; 2018.

7. MINSA: Decreto Supremo N 033-2015-SA. In. Edited by Lima. Perú: Ministerio de Salud; 2015.

8. Organization WH: WHO guideline on health policy and system support to optimize community health worker programmes: World Health Organization; 2018.

9. Informática INdEe: Perú: Crecimiento y Distribución de la Población 2017. Perú: INEl; 2018.

10. Organization WH: Mental Health ATLAS 2017 Member State Profile. In.; 2018.

11. Shields G, Ng R, Ventriglio A, Castaldelli-Maia J, Torales J, Bhugra D: WPA Position Statement on Recruitment in Psychiatry. World Psychiatry 2017, 16(1):113-114.

12. MINSA: Resolución Ministerial N 1357-2018-MINSA. In. Edited by Lima: MINSA; 2018: 70.

13. MINSA: Lineamientos de política sectorial en salud mental: Perú 2018: MINSA; 2018.

14. Costa C: Shortage Of Mental Health Professionals. Health Aff (Millwood) 2016, 35(10).

15. MINSA: Norma Técnica de Salud. Centros de Salud Mental Comunitarios. Peru; 2017.

16. ¿Qué hacemos? [https://www.gob.pe/4504-superintendencia-nacional-de-educacion-superior-universitaria-quehacemos]

17. Arksey H, O'Malley L: Scoping studies: towards a methodological framework. International Journal of Social Research Methodology 2005, 8(1):19-32.

18. Te cuido, me cuidas, nos cuidamos. Por una convivencia saludable. [minsa.gob.pe/salud-mental/]

19. Pueblo Dd: Supervisión a los Centros de Salud Mental Comunitario. Lima-Perú: Defensoría del Pueblo; 2019.

20. Jiménez MM, Mantilla E, Huayanay-Espinoza CA, Gil K, García H, Miranda JJ: Mercado de formación y disponibilidad de profesionales de ciencias de la salud en el Perú. Revista Peruana de Medicina Experimental y Salud Publica 2015, 32:41-50.

21. TUNI.PE. Sistema de Información Universitaria [https://www.tuni.pe/]

22. CONAREME I Consejo Nacional de Residentado Médico [https://www.conareme.org.pe/web/]

23. R: A language and environment for statistical computing [https://www.R-project.org/.] 
24. Valor Remuneración Mínima Vital (sueldo mínimo) [https://www.gob.pe/476-valor-remuneracion-minima-vitalsueldo-minimo]

25. Crivello G: 'Becoming somebody': youth transitions through education and migration in Peru. Journal of Youth Studies 2011, 14(4):395-411.

26. Organización para las M: Migraciones internas en el Perú: Organización para las Migraciones (OIM); 2015.

27. Médico D: CTM: “Los equipos médicos solo duran meses debido al intrusismo”. In. Peru: Diario Médico; 2019.

28. Superintendencia Nacional de Educación S: Il Informe Bienal sobre la Realidad Universitaria en el Perú. Peru: Superintendencia Nacional de Educación Superior Universitaria; 2020.

29. Metodología del Ranking QS World [https://dape.pucp.edu.pe/metodologia-del-ranking-qs-world/]

30. Compendio Estadístico 2019

[https://ogpl.unmsm.edu.pe/resources/Publicaciones/Compendios/Compendio2019/Cap2.html]

31. Isaac M, Ahmed HU, Chaturvedi SK, Hopwood MJ, Javeed A, Kanba S, Mufti AA, Maramis A, Samaniego RM, Udomratn $\mathrm{P}$ et al: Postgraduate training in psychiatry in Asia. Current Opinion in Psychiatry 2018, 31(5):396402.

32. Concurso de Admisión 2021 CONAREME [https://www.conareme.org.pe/web/proceso-de-admision-2021.php]

33. Akiyama T, Bernick $P$, Matsumoto $S$, Tagawa A: Recent developments in undergraduate education in psychiatry in Japan. Int Rev Psychiatry Abingdon Engl 2020, 32(2):172-177.

34. García-Valdecasas J, Vispe A, García-Valdecasas V, Hernández M: Towards a new paradigm in Psychiatry? Norte de salud mental 2016, 14(55):20-30.

35. Alcántara Moreno G: La definición de salud de la Organización Mundial de la Salud y la interdisciplinariedad. Sapiens Revista Universitaria de Investigación 2008, 9(1):93-107.

36. Papalini V, Avelín M: Medical pluralism: regulations and health concepts in six Latin American countries. Revista Perfiles Latinoamericanos 2021, 39(59).

37. Telles Correia D, Stoyanov D, Rocha Neto HG: How to define today a medical disorder? Biological and psychosocial disadvantages as the paramount criteria. Journal of Evaluation in Clinical Practice 2021:1-10.

38. Kuzman MR, Giacco D Fau - Simmons M, Simmons M Fau - Wuyts P, Wuyts P Fau - Bausch-Becker N, BauschBecker N Fau - Favre G, Favre G Fau - Nawka A, Nawka A: Psychiatry training in Europe: views from the trenches. (1466-187X (Electronic)).

39. García Laborda A: Formación en enfermería de salud mental. Rev Asoc Esp Neuropsiq 2007, 27:195-199.

40. Lambert G, Gournay K: Training for the mental health workforce: a review of developments in the United Kingdom. The Australian and New Zealand journal of psychiatry 1999, 33(5):694-700.

41. Klappenbach H: La formación universitaria en psicología en Argentina: perspectivas actuales y desafíos a la luz de la historia \%J Universitas Psychologica. 2015, 14:937-960.

42. Levenson RW: Clinical Psychology Training: Accreditation and Beyond. Annual Review of Clinical Psychology 2017, 13(1):1-22.

43. Goghari VM, Hagstrom S, Madon S, Messer-Engel K: Experiences and learnings from professional psychology training partners during the COVID-19 pandemic: Impacts, challenges, and opportunities. Canadian Psychology/Psychologie canadienne 2020, 61(3):167-189.

44. Gallo CE: Significados y contribuciones de las prácticas profesionales a la formación de pregrado en psicología. Avances en Psicología Latinoamericana 2018, 36(3):569-584. 
45. Ramírez Ramírez L: Dilemas y tensiones en la transición del aula universitaria a la práctica preprofesional en estudiantes de psicología. Educación 2016, 25:29-51.

46. Yang YO, Kim M, Park KY, Yang JH: Factors influencing the confidence in core clinical skills among hospital nurses. Int J Nurs Pract 2015, 21(6):831-838.

47. Godwin P: Training health workers: what needs to be taught and who should teach it. (0277-9536 (Print)).

48. Toyama M, Castillo H, Galea JT, Brandt LR, Mendoza M, Herrera V, Mitrani M, Cutipé Y, Cavero V, Diez-Canseco F et al: Peruvian Mental Health Reform: A Framework for Scaling-up Mental Health Services. International Journal of Health Policy and Management 2017, 6(9):501-508.

49. Razzouk D, Gregório G Fau - Antunes R, Antunes R Fau - Mari JDEJ, Mari JD: Lessons learned in developing community mental health care in Latin American and Caribbean countries. World Psychiatry 2012, 11:191-195.

50. Scorza P, Cutipe Y, Mendoza M, Arellano C, Galea JT, Wainberg ML: Lessons From Rural Peru in Integrating Mental Health Into Primary Care. Psychiatr Serv 2019, 70(1):82-84.

51. Puertas EB, Orellana RA, Muñoz BE, Jiménez JA, Medina Quiroz IG, Terrón L, Florencio A, Leal HM, Vindell JJ: Factors influencing the choice of a career in primary care among medical students in Central America. Rev Panam Salud Publica 2020, 44:e94-e94.

52. Zegarra Rojas O: Modelo de licenciamiento de los programas de pregrado de Medicina en el Perú. Acta méd Peru 2019, 36(4):301-308.

53. García Cabrera HE, Díaz Urteaga P, Ávila Chávez D, Cuzco Ruiz MZ: La Reforma del Sector Salud y los recursos humanos en salud \%J Anales de la Facultad de Medicina. 2015, 76:7-26.

54. Organización Panamericana de la S, Organización Mundial de la S: Estrategia de recursos humanos para el acceso universal a la salud y la cobertura universal de salud. In.: Organización Panamericana de la Salud; 2017.

55. Gonçalves Brasil F, de Mattos e Silva IH, Zambello AV: The Effects of Policy Change on Brazil's Public Higher Education System. Latin American Policy 2017, 8(2):313-331.

56. Barteit S, Guzek D, Jahn A, Bärnighausen T, Jorge MM, Neuhann F: Evaluation of elearning for medical education in low- and middle-income countries: A systematic review. Comput Educ 2020, 145:1 - 18.

57. Frehywot S, Vovides Y, Talib Z, Mikhail N, Ross H, Wohltjen H, Bedada S, Korhumel K, Koumare AK, Scott J: Elearning in medical education in resource constrained low- and middle-income countries. Human Resources for Health 2013, 11(1):4.

58. Yahuarcani IO, Llaja LAS, Satalaya AMN, Alva EAR, Pezo AR, Gómez EG, Díaz JEG: Mobile Applications as Tools for Virtual Education in Indigenous Communities During the COVID-19 Pandemic in the Peruvian Amazon. In: 2020 3rd International Conference of Inclusive Technology and Education (CONTIE): 28-30 Oct. 2020 2020; 2020: 215-221.

59. MINSA: Plan nacional de formación profesional y desarrollo de capacidades de los recursos humanos en salud: Planes Bicentenario 2018 - 2021: Ministerio de Salud; 2019.

60. Vargas HM, Heringer RR: Políticas de permanência no ensino superior público em perspectiva comparada: Argentina, Brasil e Chile. Archivos Analíticos de Políticas Educativas=Education Policy Analysis Archives 2017, 25(1):72.

\section{Tables}

Table 1. Characteristics of second specialty and subspecialty programs in Medicine $(n=38)$. 


\begin{tabular}{|c|c|c|c|c|c|c|}
\hline Program & University & Location & $\begin{array}{l}\text { Duration } \\
\text { (years) }\end{array}$ & $\begin{array}{l}\text { Cost for } \\
\text { studies }\end{array}$ & $\begin{array}{l}\text { Total cost } \\
(\mathrm{s} / .)\end{array}$ & $\begin{array}{l}\text { Form of } \\
\text { learning }\end{array}$ \\
\hline $\begin{array}{l}\text { 1. Second specialty in } \\
\text { Psychiatry }\end{array}$ & $\begin{array}{l}\text { Universidad } \\
\text { Católica Santa } \\
\text { María }\end{array}$ & Arequipa & 3 & $\$ 11,427.30$ & $\begin{array}{l}\$ \\
11,776.22\end{array}$ & $\begin{array}{l}\text { mainly } \\
\text { hospital }\end{array}$ \\
\hline $\begin{array}{l}\text { 2. Second specialty in } \\
\text { Community Family } \\
\text { Medicine }\end{array}$ & $\begin{array}{l}\text { Universidad } \\
\text { Católica Santa } \\
\text { María }\end{array}$ & 3 & $\$$ & $\begin{array}{l}\$ \\
11,938.07\end{array}$ & $\begin{array}{l}\text { mainly } \\
\text { hospital }\end{array}$ & \\
\hline $\begin{array}{l}\text { 3. Second specialty in } \\
\text { Psychiatry }\end{array}$ & $\begin{array}{l}\text { Universidad de San } \\
\text { Martín de Porres }\end{array}$ & Lima & 3 & $\$ 8,289.14$ & $\begin{array}{l}\$ \\
8,576.37\end{array}$ & $\begin{array}{l}\text { mainly } \\
\text { hospital }\end{array}$ \\
\hline $\begin{array}{l}\text { 4. Second specialty in } \\
\text { Community Family } \\
\text { Medicine }\end{array}$ & $\begin{array}{l}\text { Universidad de San } \\
\text { Martín de Porres }\end{array}$ & Lima & 3 & $\$ 8,289.14$ & $\begin{array}{l}\$ \\
8,762.618\end{array}$ & $\begin{array}{l}\text { mainly } \\
\text { hospital }\end{array}$ \\
\hline $\begin{array}{l}\text { 5. Second specialty in } \\
\text { Psychiatry }\end{array}$ & $\begin{array}{l}\text { Universidad } \\
\text { Nacional de Trujillo }\end{array}$ & Trujillo & 3 & $\$ 3,062.75$ & $\$ 3,376.94$ & $\begin{array}{l}\text { mainly } \\
\text { hospital }\end{array}$ \\
\hline $\begin{array}{l}\text { 6. Second specialty in } \\
\text { Community Family } \\
\text { Medicine }\end{array}$ & $\begin{array}{l}\text { Universidad } \\
\text { Nacional de Trujillo }\end{array}$ & Trujillo & 3 & $\$ 3,062.75$ & $\$ 3,513.89$ & $\begin{array}{l}\text { mainly } \\
\text { hospital }\end{array}$ \\
\hline $\begin{array}{l}\text { 7. Second specialty in } \\
\text { Psychiatry }\end{array}$ & $\begin{array}{l}\text { Universidad } \\
\text { Nacional Federico } \\
\text { Villarreal }\end{array}$ & Lima & 3 & $\$ 2,883.47$ & $\$ 3,220.07$ & $\begin{array}{l}\text { mainly } \\
\text { hospital }\end{array}$ \\
\hline $\begin{array}{l}\text { 8. Second specialty in } \\
\text { Community Family } \\
\text { Medicine }\end{array}$ & $\begin{array}{l}\text { Universidad } \\
\text { Nacional Federico } \\
\text { Villarreal }\end{array}$ & Lima & 3 & $\$ 2,883.47$ & $\$ 3,381.92$ & $\begin{array}{l}\text { mainly } \\
\text { hospital }\end{array}$ \\
\hline $\begin{array}{l}\text { 9. Second specialty in } \\
\text { Psychiatry }\end{array}$ & $\begin{array}{l}\text { Universidad } \\
\text { Nacional Mayor de } \\
\text { San Marcos }\end{array}$ & Lima & 3 & $\$ 4,855.58$ & $\$ 5,154.80$ & $\begin{array}{l}\text { mainly } \\
\text { hospital }\end{array}$ \\
\hline $\begin{array}{l}\text { 10. Second specialty } \\
\text { in Community Family } \\
\text { Medicine }\end{array}$ & $\begin{array}{l}\text { Universidad } \\
\text { Nacional Mayor de } \\
\text { San Marcos }\end{array}$ & Lima & 3 & $\$ 4,855.58$ & $\$ 5,316.65$ & $\begin{array}{l}\text { mainly } \\
\text { hospital }\end{array}$ \\
\hline $\begin{array}{l}\text { 11. Second specialty } \\
\text { in Psychiatry }\end{array}$ & $\begin{array}{l}\text { Universidad } \\
\text { Peruana Cayetano } \\
\text { Heredia }\end{array}$ & Lima & 3 & $\$ 9,053.78$ & $\$ 9,370.38$ & $\begin{array}{l}\text { mainly } \\
\text { hospital }\end{array}$ \\
\hline $\begin{array}{l}\text { 12. Second specialty } \\
\text { in Community Family } \\
\text { Medicine }\end{array}$ & $\begin{array}{l}\text { Universidad } \\
\text { Peruana Cayetano } \\
\text { Heredia }\end{array}$ & Lima & 3 & $\$ 8,784.86$ & $\$ 9,532.29$ & $\begin{array}{l}\text { mainly } \\
\text { hospital }\end{array}$ \\
\hline $\begin{array}{l}\text { 13. Second specialty } \\
\text { in Psychiatry }\end{array}$ & $\begin{array}{l}\text { Universidad Privada } \\
\text { Antenor Orrego }\end{array}$ & Trujillo & 3 & $\$ 7,918.33$ & $\$ 8,269.80$ & $\begin{array}{l}\text { mainly } \\
\text { hospital }\end{array}$ \\
\hline $\begin{array}{l}\text { 14. Second specialty } \\
\text { in Community Family } \\
\text { Medicine }\end{array}$ & $\begin{array}{l}\text { Universidad Privada } \\
\text { Antenor Orrego }\end{array}$ & Trujillo & 3 & $\$ 7,918.33$ & $\$ 8,431.65$ & $\begin{array}{l}\text { mainly } \\
\text { hospital }\end{array}$ \\
\hline $\begin{array}{l}\text { 15. Second specialty } \\
\text { in Psychiatry }\end{array}$ & $\begin{array}{l}\text { Universidad Privada } \\
\text { San Juan Bautista }\end{array}$ & Lima & 3 & $\$ 5,328.69$ & $\$ 8,379.36$ & $\begin{array}{l}\text { mainly } \\
\text { hospital }\end{array}$ \\
\hline $\begin{array}{l}\text { 16. Second specialty } \\
\text { in Community Family } \\
\text { Medicine }\end{array}$ & $\begin{array}{l}\text { Universidad Privada } \\
\text { San Juan Bautista }\end{array}$ & Lima & 3 & $\$ 5,328.69$ & $\$ 8,541.21$ & $\begin{array}{l}\text { mainly } \\
\text { hospital }\end{array}$ \\
\hline
\end{tabular}




\begin{tabular}{|c|c|c|c|c|c|c|}
\hline $\begin{array}{l}\text { 17. Second specialty } \\
\text { in Psychiatry }\end{array}$ & $\begin{array}{l}\text { Universidad Ricardo } \\
\text { Palma }\end{array}$ & Lima & 3 & $\$ 7,395.42$ & $\$ 7,682.16$ & $\begin{array}{l}\text { mainly } \\
\text { hospital }\end{array}$ \\
\hline $\begin{array}{l}\text { 18. Second specialty } \\
\text { in Community Family } \\
\text { Medicine }\end{array}$ & $\begin{array}{l}\text { Universidad Ricardo } \\
\text { Palma }\end{array}$ & Lima & 3 & $\$ 7,395.42$ & $\$ 7,844.01$ & $\begin{array}{l}\text { mainly } \\
\text { hospital }\end{array}$ \\
\hline $\begin{array}{l}\text { 19. Second specialty } \\
\text { in Community Family } \\
\text { Medicine }\end{array}$ & $\begin{array}{l}\text { Universidad } \\
\text { Nacional del } \\
\text { Altiplano }\end{array}$ & Puno & 3 & $\$ 4,033.86$ & 4,407.80\$ & $\begin{array}{l}\text { mainly } \\
\text { hospital }\end{array}$ \\
\hline $\begin{array}{l}\text { 20. Second specialty } \\
\text { in Community Family } \\
\text { Medicine }\end{array}$ & $\begin{array}{l}\text { Universidad } \\
\text { Científica del Sur }\end{array}$ & Lima & 3 & $\$ 8,695.22$ & $\$ 9,218.49$ & $\begin{array}{l}\text { mainly } \\
\text { hospital }\end{array}$ \\
\hline $\begin{array}{l}\text { 21. Second specialty } \\
\text { in Community Family } \\
\text { Medicine }\end{array}$ & $\begin{array}{l}\text { Universidad } \\
\text { Peruana de los } \\
\text { Andes }\end{array}$ & Junín & 3 & $\$ 9,860.56$ & $\begin{array}{l}\$ \\
10,408.71\end{array}$ & $\begin{array}{l}\text { mainly } \\
\text { hospital }\end{array}$ \\
\hline $\begin{array}{l}\text { 22. Second specialty } \\
\text { in Community Family } \\
\text { Medicine }\end{array}$ & $\begin{array}{l}\text { Universidad César } \\
\text { Vallejo }\end{array}$ & Trujillo & 3 & $\$ 6,835.16$ & $\$ 7,326.09$ & $\begin{array}{l}\text { mainly } \\
\text { hospital }\end{array}$ \\
\hline $\begin{array}{l}\text { 23. Second specialty } \\
\text { in Community Family } \\
\text { Medicine }\end{array}$ & $\begin{array}{l}\text { Universidad } \\
\text { Nacional de Piura }\end{array}$ & Piura & 3 & $\$ 3,432.89$ & $\$ 3,806.84$ & $\begin{array}{l}\text { mainly } \\
\text { hospital }\end{array}$ \\
\hline $\begin{array}{l}\text { 24. Second specialty } \\
\text { in Community Family } \\
\text { Medicine }\end{array}$ & $\begin{array}{l}\text { Universidad } \\
\text { Nacional del Centro } \\
\text { del Perú }\end{array}$ & Junín & 3 & $\begin{array}{l}\$ \\
11,205.20\end{array}$ & $\begin{array}{l}\$ \\
11,683.59\end{array}$ & $\begin{array}{l}\text { mainly } \\
\text { hospital }\end{array}$ \\
\hline $\begin{array}{l}\text { 25. Second specialty } \\
\text { in Community Family } \\
\text { Medicine }\end{array}$ & $\begin{array}{l}\text { Universidad } \\
\text { peruana de Ciencias } \\
\text { Aplicadas }\end{array}$ & Lima & 3 & $\$ 9,053.78$ & $\$ 9,532.23$ & $\begin{array}{l}\text { mainly } \\
\text { hospital }\end{array}$ \\
\hline $\begin{array}{l}\text { 26. Second specialty } \\
\text { in Psychiatry* }\end{array}$ & $\begin{array}{l}\text { Universidad } \\
\text { Nacional de San } \\
\text { Agustín }\end{array}$ & Arequipa & 3 & $\$ 3,959.16$ & No report & $\begin{array}{l}\text { mainly } \\
\text { hospital }\end{array}$ \\
\hline $\begin{array}{l}\text { 27. Second specialty } \\
\text { in Community Family } \\
\text { Medicine* }\end{array}$ & $\begin{array}{l}\text { Universidad } \\
\text { Nacional de San } \\
\text { Agustín }\end{array}$ & Arequipa & 3 & $\$ 3,959.16$ & No report & $\begin{array}{l}\text { mainly } \\
\text { hospital }\end{array}$ \\
\hline $\begin{array}{l}\text { 28. Second specialty } \\
\text { in Psychiatry* }\end{array}$ & $\begin{array}{l}\text { Universidad Privada } \\
\text { de Tacna }\end{array}$ & Tacna & 3 & $\$ 9,412.35$ & No report & $\begin{array}{l}\text { mainly } \\
\text { hospital }\end{array}$ \\
\hline $\begin{array}{l}\text { 29. Second specialty } \\
\text { in Community Family } \\
\text { Medicine* }\end{array}$ & $\begin{array}{l}\text { Universidad Privada } \\
\text { de Tacna }\end{array}$ & Tacna & 3 & $\$ 9,412.35$ & No report & $\begin{array}{l}\text { mainly } \\
\text { hospital }\end{array}$ \\
\hline $\begin{array}{l}\text { 30. Second specialty } \\
\text { in Community Family } \\
\text { Medicine* }\end{array}$ & $\begin{array}{l}\text { Universidad } \\
\text { Nacional de San } \\
\text { Antonio Abad del } \\
\text { Cusco }\end{array}$ & Cusco & 3 & $\$ 1,063.75$ & No report & $\begin{array}{l}\text { mainly } \\
\text { hospital }\end{array}$ \\
\hline $\begin{array}{l}\text { 31. Second specialty } \\
\text { in Community Family } \\
\text { Medicine* }\end{array}$ & $\begin{array}{l}\text { Universidad } \\
\text { Nacional de la } \\
\text { Amazonía Peruana }\end{array}$ & Loreto & 3 & No report & No report & $\begin{array}{l}\text { mainly } \\
\text { hospital }\end{array}$ \\
\hline $\begin{array}{l}\text { 32. Subspecialty in } \\
\text { Addiction Psychiatry }\end{array}$ & $\begin{array}{l}\text { Universidad de San } \\
\text { Martín de Porres }\end{array}$ & Lima & 2 & $\$ 5,526.10$ & $\$ 5,837.76$ & $\begin{array}{l}\text { mainly } \\
\text { hospital }\end{array}$ \\
\hline $\begin{array}{l}\text { 33. Subspecialty in } \\
\text { Child and Adolescent } \\
\text { Psychiatry }\end{array}$ & $\begin{array}{l}\text { Universidad de San } \\
\text { Martín de Porres }\end{array}$ & Lima & 2 & $\$ 5,526.10$ & $\$ 5,837.76$ & $\begin{array}{l}\text { mainly } \\
\text { hospital }\end{array}$ \\
\hline
\end{tabular}




\begin{tabular}{|c|c|c|c|c|c|c|}
\hline $\begin{array}{l}\text { 34. Subspecialty in } \\
\text { Child and Adolescent } \\
\text { Psychiatry }\end{array}$ & $\begin{array}{l}\text { Universidad } \\
\text { Nacional Federico } \\
\text { Villarreal }\end{array}$ & Lima & 2 & $\$ 1,922.31$ & $\$ 2,258.93$ & $\begin{array}{l}\text { mainly } \\
\text { hospital }\end{array}$ \\
\hline $\begin{array}{l}\text { 35. Subspecialty in } \\
\text { Child and Adolescent } \\
\text { Psychiatry }\end{array}$ & $\begin{array}{l}\text { Universidad } \\
\text { Nacional Mayor de } \\
\text { San Marcos }\end{array}$ & Lima & 2 & $\$ 3,237.05$ & $\$ 3,536.30$ & $\begin{array}{l}\text { mainly } \\
\text { hospital }\end{array}$ \\
\hline $\begin{array}{l}\text { 36. Subspecialty in } \\
\text { Addiction Psychiatry }\end{array}$ & $\begin{array}{l}\text { Universidad } \\
\text { Nacional Mayor de } \\
\text { San Marcos }\end{array}$ & Lima & 2 & $\$ 3,237.05$ & $\$ 3,536.30$ & $\begin{array}{l}\text { mainly } \\
\text { hospital }\end{array}$ \\
\hline $\begin{array}{l}\text { 37. Subspecialty in } \\
\text { Child and Adolescent } \\
\text { Psychiatry }\end{array}$ & $\begin{array}{l}\text { Universidad } \\
\text { Peruana Cayetano } \\
\text { Heredia }\end{array}$ & Lima & 2 & $\$ 8,784.86$ & $\$ 9,101.46$ & $\begin{array}{l}\text { mainly } \\
\text { hospital }\end{array}$ \\
\hline $\begin{array}{l}\text { 38. Subspecialty in } \\
\text { Child and Adolescent } \\
\text { Psychiatry }\end{array}$ & $\begin{array}{l}\text { Universidad Ricardo } \\
\text { Palma }\end{array}$ & Lima & 2 & $\$ 4,930.28$ & \$ 5,217.05 & $\begin{array}{l}\text { mainly } \\
\text { hospital }\end{array}$ \\
\hline
\end{tabular}

Source. Own elaboration

The Peruvian sol is equivalent to 0,25 dollars

Cost for studies: consist of the monthly fees and tuition

Total cost: consist of the tuition, monthly fees and enrolment

Table 2. Characteristics of the Second Specialty Nursing Programs $(n=16)$. 


\begin{tabular}{|c|c|c|c|c|c|c|}
\hline Program & University & Location & $\begin{array}{l}\text { Duration } \\
\text { (years) }\end{array}$ & $\begin{array}{l}\text { Cost for } \\
\text { studies }\end{array}$ & $\begin{array}{l}\text { Total } \\
\text { cost } \\
(\mathrm{s} / .)\end{array}$ & $\begin{array}{l}\text { Form of } \\
\text { learning }\end{array}$ \\
\hline $\begin{array}{l}\text { 1.Second interdisciplinary } \\
\text { specialty with mention in: } \\
\text { health, mental health and } \\
\text { psychiatry. }\end{array}$ & $\begin{array}{l}\text { Universidad } \\
\text { Nacional de } \\
\text { Ucayali }\end{array}$ & Ucayali & $11 / 2$ & $\$$ & $\$$ & $\begin{array}{l}\text { mainly } \\
\text { hospital }\end{array}$ \\
\hline $\begin{array}{l}\text { 2. Second professional } \\
\text { specialty in mental health } \\
\text { nursing }\end{array}$ & $\begin{array}{l}\text { Universidad } \\
\text { Nacional del } \\
\text { Callao }\end{array}$ & Callao & 1 & $\begin{array}{l}\$ \\
697.21\end{array}$ & $\begin{array}{l}\$ \\
717.12\end{array}$ & $\begin{array}{l}\text { mainly } \\
\text { hospital }\end{array}$ \\
\hline $\begin{array}{l}\text { 3. Second professional } \\
\text { specialty in public and } \\
\text { community health }\end{array}$ & $\begin{array}{l}\text { Universidad } \\
\text { Nacional del } \\
\text { Callao }\end{array}$ & Callao & 1 & $\begin{array}{l}\$ \\
697.21\end{array}$ & $\begin{array}{l}\$ \\
717.12\end{array}$ & $\begin{array}{l}\text { mainly } \\
\text { hospital }\end{array}$ \\
\hline $\begin{array}{l}\text { 4. Mental Health and } \\
\text { Psychiatric Nursing }\end{array}$ & $\begin{array}{l}\text { Universidad } \\
\text { Nacional Federico } \\
\text { Villarreal }\end{array}$ & Lima & 2 & $\begin{array}{l}\$ \\
1,494.02\end{array}$ & $\stackrel{\$}{1,568.70}$ & $\begin{array}{l}\text { mainly } \\
\text { hospital }\end{array}$ \\
\hline $\begin{array}{l}\text { 5. Second Nursing Specialty } \\
\text { in Public and Community } \\
\text { Health }\end{array}$ & $\begin{array}{l}\text { Universidad } \\
\text { Nacional Federico } \\
\text { Villarreal }\end{array}$ & Lima & 2 & $\begin{array}{l}\$ \\
1,494.02\end{array}$ & $\stackrel{\$}{1,568.70}$ & $\begin{array}{l}\text { mainly } \\
\text { hospital }\end{array}$ \\
\hline $\begin{array}{l}\text { 6. Second Nursing Specialty } \\
\text { in Mental Health and } \\
\text { Psychiatry }\end{array}$ & $\begin{array}{l}\text { Universidad } \\
\text { Nacional Mayor } \\
\text { de San Marcos }\end{array}$ & Lima & 2 & $\begin{array}{l}\$ \\
1,992.03\end{array}$ & $\begin{array}{l}\$ \\
2,131.44\end{array}$ & $\begin{array}{l}\text { mainly } \\
\text { hospital }\end{array}$ \\
\hline $\begin{array}{l}\text { 7. Second Public Health } \\
\text { Nursing Specialty }\end{array}$ & $\begin{array}{l}\text { Universidad } \\
\text { Nacional Mayor } \\
\text { de San Marcos }\end{array}$ & Lima & 2 & $\begin{array}{l}\$ \\
1,992.03\end{array}$ & $\begin{array}{l}\mathbf{S} \\
2,131.44\end{array}$ & $\begin{array}{l}\text { mainly } \\
\text { hospital }\end{array}$ \\
\hline $\begin{array}{l}\text { 8. Second Specialty of } \\
\text { Nursing in Mental Health and } \\
\text { Psychiatry }\end{array}$ & $\begin{array}{l}\text { Universidad } \\
\text { Peruana Cayetano } \\
\text { Heredia }\end{array}$ & Lima & $11 / 2$ & $\begin{array}{l}\$ \\
3,361.55\end{array}$ & $\begin{array}{l}\$ \\
3,473.55\end{array}$ & $\begin{array}{l}\text { mainly } \\
\text { hospital }\end{array}$ \\
\hline $\begin{array}{l}\text { 9. Second Specialty of } \\
\text { Nursing in Mental Health and } \\
\text { Psychiatry }\end{array}$ & $\begin{array}{l}\text { Universidad } \\
\text { Privada Norbert } \\
\text { Wiener }\end{array}$ & Lima & $11 / 2$ & $\begin{array}{l}\$ \\
1,718.13\end{array}$ & $\begin{array}{l}\$ \\
1,792.80\end{array}$ & $\begin{array}{l}\text { mainly } \\
\text { hospital }\end{array}$ \\
\hline $\begin{array}{l}\text { 10. Second Specialty of } \\
\text { Nursing in Public Health and } \\
\text { Health Services Management }\end{array}$ & $\begin{array}{l}\text { Universidad } \\
\text { Nacional de San } \\
\text { Antonio Abad del } \\
\text { Cusco }\end{array}$ & Cusco & 1 & $\begin{array}{l}\$ \\
996.02\end{array}$ & $\begin{array}{l}\$ \\
1,073.94\end{array}$ & $\begin{array}{l}\text { mainly } \\
\text { hospital }\end{array}$ \\
\hline $\begin{array}{l}\text { 11. Second Specialty in } \\
\text { Public and Community } \\
\text { Health Nursing }\end{array}$ & $\begin{array}{l}\text { Universidad } \\
\text { Nacional Jorge } \\
\text { Basadre } \\
\text { Grohmann }\end{array}$ & Tacna & 1 & $\begin{array}{l}\$ \\
781.87\end{array}$ & $\begin{array}{l}\$ \\
806.76\end{array}$ & $\begin{array}{l}\text { mainly } \\
\text { hospital }\end{array}$ \\
\hline $\begin{array}{l}\text { 12. Second Specialty in } \\
\text { Family and Community } \\
\text { Health Nursing }\end{array}$ & $\begin{array}{l}\text { Universidad de } \\
\text { San Martín de } \\
\text { Porres }\end{array}$ & Lima & 1 & $\begin{array}{l}\$ \\
1,157.13\end{array}$ & $\begin{array}{l}\$ \\
1,179.02\end{array}$ & $\begin{array}{l}\text { mainly } \\
\text { hospital }\end{array}$ \\
\hline $\begin{array}{l}\text { 13. Second Public Health } \\
\text { Nursing Specialty }\end{array}$ & $\begin{array}{l}\text { Universidad de } \\
\text { San Martín de } \\
\text { Porres }\end{array}$ & Lima & 1 & $\$$ & $\$$ & $\begin{array}{l}\text { mainly } \\
\text { hospital }\end{array}$ \\
\hline $\begin{array}{l}\text { 14.Second specialty in } \\
\text { mental health nursing and } \\
\text { psychiatry }\end{array}$ & $\begin{array}{l}\text { Universidad } \\
\text { Nacional de la } \\
\text { Amazonía } \\
\text { Peruana }\end{array}$ & Iquitos & $\begin{array}{l}\text { No } \\
\text { report }\end{array}$ & & $\begin{array}{l}\text { No } \\
\text { report }\end{array}$ & $\begin{array}{l}\text { No } \\
\text { report }\end{array}$ \\
\hline
\end{tabular}




\begin{tabular}{|c|c|c|c|c|c|}
\hline $\begin{array}{l}\text { 15.Second Professional } \\
\text { Specialty in Public and } \\
\text { Community Health Nursing }\end{array}$ & $\begin{array}{l}\text { Universidad } \\
\text { Nacional de la } \\
\text { Amazonía } \\
\text { Peruana }\end{array}$ & Iquitos & $\begin{array}{l}\text { No } \\
\text { report }\end{array}$ & $\begin{array}{l}\text { No } \\
\text { report }\end{array}$ & $\begin{array}{l}\text { No } \\
\text { report }\end{array}$ \\
\hline $\begin{array}{l}\text { 16.Second nursing specialty } \\
\text { in Mint Health }\end{array}$ & $\begin{array}{l}\text { Universidad } \\
\text { Nacional de San } \\
\text { Agustín }\end{array}$ & Arequipa & 1 & $\begin{array}{l}\text { No } \\
\text { report }\end{array}$ & $\begin{array}{l}\text { No } \\
\text { report }\end{array}$ \\
\hline
\end{tabular}

Source. Own elaboration

The Peruvian sol is equivalent to 0,25 dollars

Cost for studies: consist of the monthly fees and tuition

Total cost: consist of the tuition, monthly fees and enrolment

Table 3. Characteristics of second specialties in Psychology $(n=6)$.

\begin{tabular}{|c|c|c|c|c|c|c|}
\hline Program & University & Location & $\begin{array}{l}\text { Duration } \\
\text { (years) }\end{array}$ & $\begin{array}{l}\text { Cost for } \\
\text { studies }\end{array}$ & $\begin{array}{l}\text { Total } \\
\text { cost } \\
\text { (s/.) }\end{array}$ & $\begin{array}{l}\text { Form of } \\
\text { learning }\end{array}$ \\
\hline $\begin{array}{l}\text { 1. Systemic Family } \\
\text { Psychotherapy }\end{array}$ & $\begin{array}{l}\text { Universidad } \\
\text { Nacional } \\
\text { Federico } \\
\text { Villarreal }\end{array}$ & Lima & 2 & $\$ 2,589.64$ & $\begin{array}{l}\$ \\
2,626.95\end{array}$ & $\begin{array}{l}\text { Mainly in } \\
\text { classrooms }\end{array}$ \\
\hline $\begin{array}{l}\text { 2. Cognitive Behavioural } \\
\text { Therapy }\end{array}$ & $\begin{array}{l}\text { Universidad } \\
\text { Nacional } \\
\text { Federico } \\
\text { Villarreal }\end{array}$ & Lima & 2 & $\begin{array}{l}\$ \\
2,589.64\end{array}$ & $\begin{array}{l}\$ \\
2,626.95\end{array}$ & $\begin{array}{l}\text { Mainly in } \\
\text { classrooms }\end{array}$ \\
\hline $\begin{array}{l}\text { 3. Second speciality in } \\
\text { Family Therapy and } \\
\text { Systematic Intervention } \\
\text { with a focus on violence } \\
\text { and addictions }\end{array}$ & $\begin{array}{l}\text { Universidad } \\
\text { Católica de } \\
\text { Trujillo } \\
\text { Benedicto XVI }\end{array}$ & Trujillo & 1 & \$ 846.61 & $\begin{array}{l}\$ \\
871.50\end{array}$ & $\begin{array}{l}\text { Mainly in } \\
\text { classrooms }\end{array}$ \\
\hline $\begin{array}{l}\text { 4. Second speciality in } \\
\text { Family Therapy and } \\
\text { Systematic Intervention } \\
\text { with a focus on couples } \\
\text { and sexuality }\end{array}$ & $\begin{array}{l}\text { Universidad } \\
\text { Católica de } \\
\text { Trujillo } \\
\text { Benedicto XVI }\end{array}$ & Trujillo & 1 & \$ 846.61 & $\begin{array}{l}\$ \\
871.50\end{array}$ & $\begin{array}{l}\text { Mainly in } \\
\text { classrooms }\end{array}$ \\
\hline
\end{tabular}

Source. Own elaboration

The Peruvian sol is equivalent to 0,25 dollars

Cost for studies: consist of the monthly fees and tuition

Total cost: consist of the tuition, monthly fees and enrolment

Table 4. Characteristics of Speech Therapy programmes for multidisciplinary audiences $(n=4)$ 


\begin{tabular}{|c|c|c|c|c|c|c|c|}
\hline Program & University & Location & $\begin{array}{l}\text { Duration } \\
\text { (years) }\end{array}$ & $\begin{array}{l}\text { Cost for } \\
\text { studies }\end{array}$ & $\begin{array}{l}\text { Total } \\
\text { cost } \\
(\mathrm{s} / .)\end{array}$ & $\begin{array}{l}\text { Form of } \\
\text { learning }\end{array}$ & Audience \\
\hline $\begin{array}{l}\text { 1. Second } \\
\text { speciality in } \\
\text { communication } \\
\text { and language } \\
\text { difficulties }\end{array}$ & $\begin{array}{l}\text { Pontificia } \\
\text { Universidad } \\
\text { Católica del } \\
\text { Perú }\end{array}$ & Lima & $11 / 2$ & $\begin{array}{l}\$ \\
2,285.86\end{array}$ & $\begin{array}{l}\$ \\
2,435.22\end{array}$ & $\begin{array}{l}\text { mainly } \\
\text { hospital }\end{array}$ & $\begin{array}{l}\text { Licenciatura } \\
\text { en } \\
\text { Psicología, } \\
\text { Educación y } \\
\text { Tecnología } \\
\text { Médica. }\end{array}$ \\
\hline $\begin{array}{l}\text { 2. Second } \\
\text { Professional } \\
\text { Specialisation } \\
\text { in Assessment } \\
\text { and } \\
\text { Intervention } \\
\text { Strategies for } \\
\text { Children's } \\
\text { Language } \\
\text { Difficulties }\end{array}$ & $\begin{array}{l}\text { Universidad } \\
\text { Nacional } \\
\text { Mayor de } \\
\text { San } \\
\text { Marcos }\end{array}$ & Lima & 2 & $\begin{array}{l}\$ \\
1,705.18\end{array}$ & $\begin{array}{l}\$ \\
1,705.18\end{array}$ & $\begin{array}{l}\text { Mainly in } \\
\text { classrooms }\end{array}$ & $\begin{array}{l}\text { Licenciatura } \\
\text { en } \\
\text { Psicología, } \\
\text { Educación, } \\
\text { Medicina, } \\
\text { Enfermería, } \\
\text { Lingüística y } \\
\text { profesionales } \\
\text { de carreras } \\
\text { afines. }\end{array}$ \\
\hline $\begin{array}{l}\text { 3. Second } \\
\text { speciality in } \\
\text { special } \\
\text { education: } \\
\text { hearing and } \\
\text { language }\end{array}$ & $\begin{array}{l}\text { Universidad } \\
\text { Femenina } \\
\text { del } \\
\text { Sagrado } \\
\text { Corazón }\end{array}$ & Lima & 1 & $\begin{array}{l}\$ \\
811.75\end{array}$ & $\begin{array}{l}\$ \\
864.03\end{array}$ & $\begin{array}{l}\text { mainly } \\
\text { hospital }\end{array}$ & $\begin{array}{l}\text { Licenciatura } \\
\text { en } \\
\text { Educación, } \\
\text { Psicología, } \\
\text { Terapia } \\
\text { Física y } \\
\text { Enfermería. }\end{array}$ \\
\hline $\begin{array}{l}\text { 4. Second } \\
\text { speciality in } \\
\text { speech therapy } \\
\text { and integrated } \\
\text { speech therapy }\end{array}$ & $\begin{array}{l}\text { Universidad } \\
\text { Privada de } \\
\text { Tacna }\end{array}$ & Tacna & 1 & $\begin{array}{l}\text { No } \\
\text { report }\end{array}$ & $\begin{array}{l}\text { No } \\
\text { report }\end{array}$ & $\begin{array}{l}\text { Mainly in } \\
\text { classrooms }\end{array}$ & $\begin{array}{l}\text { Licenciatura } \\
\text { en } \\
\text { Psicología, } \\
\text { Medicina, } \\
\text { Educación y } \\
\text { Enfermería. }\end{array}$ \\
\hline $\begin{array}{l}\text { 5. Second } \\
\text { speciality in } \\
\text { education } \\
\text { speciality: } \\
\text { audition and } \\
\text { language }\end{array}$ & $\begin{array}{l}\text { Universidad } \\
\text { Católica de } \\
\text { Trujillo } \\
\text { Benedicto } \\
\text { XVI }\end{array}$ & Trujillo & 1 & $\begin{array}{l}\$ \\
846.19\end{array}$ & $\begin{array}{l}\$ \\
871.08\end{array}$ & $\begin{array}{l}\text { Mainly in } \\
\text { classrooms }\end{array}$ & $\begin{array}{l}\text { Professionals } \\
\text { with a } \\
\text { university } \\
\text { degree. }\end{array}$ \\
\hline
\end{tabular}

Source. Own elaboration

The Peruvian sol is equivalent to 0,25 dollars

Cost for studies: consist of the monthly fees and tuition

Total cost: consist of the tuition, monthly fees and enrolment.

\section{Figures}



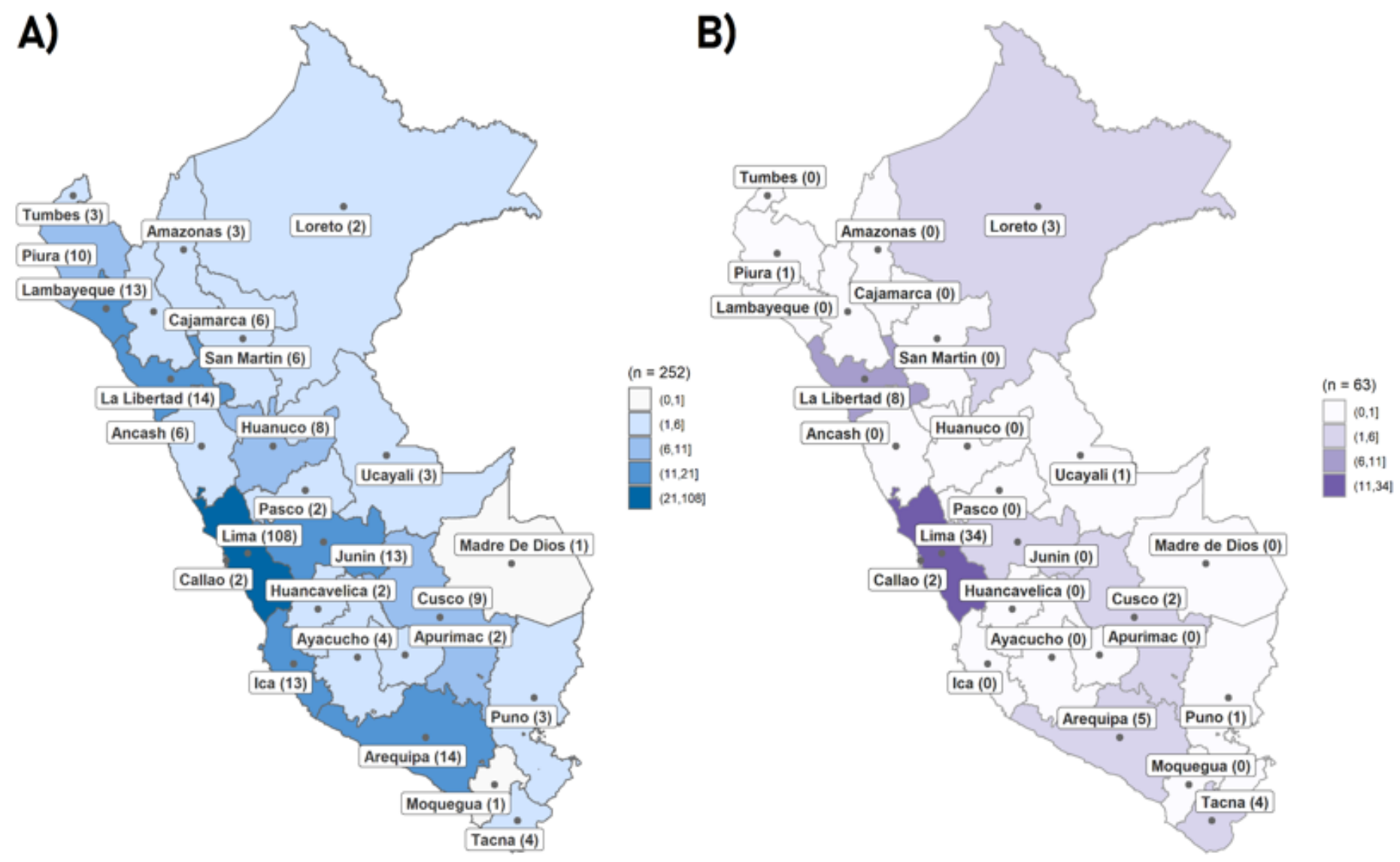

Figure 1

Distribution of undergraduate and second specialty programmes by region. Note: A) Undergraduate programmes by region. B) Second specialty programmes by region.

\section{Supplementary Files}

This is a list of supplementary files associated with this preprint. Click to download.

- Supplement1.docx

- Supplement2.docx

- Supplement3.xlsx 